\title{
Loss of expression of TGF- $\beta s$ and their receptors in chronic skin lesions induced by sulfur mustard as compared with chronic contact dermatitis patients
}

Isa Khaheshi ${ }^{1,3}$, Saeed Keshavarz ${ }^{1}$, Abbas Ali Imani Fooladi ${ }^{2}$, Majid Ebrahimi ${ }^{1}$, Samaneh Yazdani ${ }^{1}$, Yunes Panahi ${ }^{1}$, Majid Shohrati', Mohammad Reza Nourani ${ }^{1 *}$

\begin{abstract}
Background: Sulfur mustard (SM) is a blister-forming agent that has been used as a chemical weapon. Sulfur mustard can cause damage in various organs, especially the skin, respiratory system, and eyes. Generally, the multiple complications of mustard gas result from its alkalizing potency; it reacts with cellular components like DNA, RNA, proteins, and lipid membranes.

TGF- $\beta$ is a multi-functional cytokine with multiple biological effects ranging from cell differentiation and growth inhibition to extracellular matrix stimulation, immunosuppression, and immunomodulation. TGF- $\beta$ has 3 isoforms (TGF- $\beta 1,2,3$ ) and its signaling is mediated by its receptors: R1, R2 and intracellular Smads molecules.

TGF- $\beta$ has been shown to have anti-inflammatory effects. TGF- $\beta$ s and their receptors also have an important role in modulation of skin inflammation, proliferation of epidermal cells, and wound healing, and they have been implicated in different types of skin inflammatory disorders.
\end{abstract}

Methods: Seventeen exposed SM individuals (48.47 \pm 9.3 years), 17 chronic dermatitis patients (46.52 \pm 14.6 years), and 5 normal controls (44.00 \pm 14.6 years) were enrolled in this study.

Evaluation of TGF- $\beta$ s and their receptors expressions was performed by semiquantitative RT-PCR. Only TGF1was analyzed immunohistochemically.

Results: Our results showed significant decreases in the expression percentages of TGF- $\beta$ 1, 2 and R1, R2 in chemical victims in comparison with chronic dermatitis and normal subjects and significant decreases in the intensity of R1 and R2 expressions in chemical victims in comparison with chronic dermatitis and normal controls. ( $P$ value $<0.05$ )

Conclusions: TGF- $\beta$ s and their receptors appear to have a noticeable role in chronic inflammatory skin lesions caused by sulfur mustard.

\section{Background}

Sulfur mustard (SM) or mustard gas (bis-2-(chloroethyl)) sulfide is a blister-forming agent that was used as a chemical weapon [1] in World War I (1917) for the first time and against Iranian citizens during the Iraq Conflict (1980-1988), resulting in 100,000 chemically-

\footnotetext{
* Correspondence: r.nourani@yahoo.com

'Genomics Division, Chemical Injury Research Center (CIRC) Baqiyatallah University of Medical Sciences, Tehran-Iran

Full list of author information is available at the end of the article
}

injured victims[2]. Currently, one-third of these victims suffer from secondary complications [1]. SM can cause damage to various organs, especially the skin, respiratory tract, and eyes. In general, the various complications of SM are caused by its alkylating effects on cellular components such as DNA, RNA, and intramembranous proteins and lipids, resulting in metabolic and genetic damage [3-7].

In the skin, keratinocytes, particularly in the basal layer, are the main target of SM alkylation $[4,8]$. The 
major chronic skin manifestations of SM are erythema, xerosis, hypo- or hyper-pigmentation, contact dermatitis, and pruritus [9-12]. Cytokines have been shown to play a key role in acute and chronic skin inflammation, including chronic contact dermatitis due to SM [13-18]. One of these important cytokines is transforming growth factor- $\beta$ (TGF- $\beta$ ), a $25 \mathrm{KD}$ molecular weight (MW) homo-dimmer protein in its active form $[19,20]$. TGF- $\beta$ has 3 isoforms (TGF- $\beta 1,2,3$ ), Its signaling is mediated by its transmembrane receptors, $\mathrm{TR}_{1}$ and $\mathrm{TR}_{2}$, which have serine/threonine kinase activity [21]. The intracellular signaling pathway of TGF- $\beta$ is mediated by Smads molecules $[22,23]$ that eventually enter the nucleus, bind with transcription promoters/cofactors, and regulate the transcription of DNA [24-27]. TGF- $\beta$ is secreted from several cell types such as $\mathrm{T}$ cells, macrophages, platelets, endothelial cells, keratinocytes, and fibroblasts o[28,29]; it is a multi-functional cytokine with biological effects ranging from cell differentiation and growth inhibition to extracellular matrix stimulation, immuno-suppression, and immuno-modulation $[29,30]$. There have been data suggesting that the antiinflammatory effect of TGF- $\beta$ on Th1 and Th 2 production and differentiation in macrophages and dendritic cells is a key issue in the skin manifestations of SM [21,27,31-38].

To evaluate the possible role of TGF- $\beta$ and its receptors in chronic inflammatory skin lesions caused by SM and symptoms like pruritus, we attempted to assess the expression of TGF- $\beta$ and its receptors in the skin lesions of chemical-injured victims of SM in comparison with normal controls.

\section{Methods}

\section{Sampling}

The subjects of this study were 17 male SM chemicallyinjured patients between the ages of 38 and 70 without an exposure history to toxic agents other than SM, 17 male chronic contact dermatitis patients between the ages of 20 and 68 without history of exposure to SM, and 5 healthy male participants between the ages of 21 and 58. The means and standard deviations (mean \pm SD) of age were $48.47 \pm 9.3,46.52 \pm 14.6$ and $44.00 \pm$ 14.6 for MS chemically-injured patients, chronic contact dermatitis patients and normal ones, respectively, and there were no significant differences in ages among the three groups $(p>0.05)$. The chemically-injured patients had documented histories of exposure to SM during the Iran-Iraq war (1983-88), and the chronic contact dermatitis patients had sought ambulatory medical treatment at a dermatology hospital. People with histories of addiction or topical treatment during the 48 hours before biopsy were excluded from the study. Informed consent was obtained from all the patients and normal men to be examined, and all of them were aware of the probable consequences of a skin biopsy.

The severity of the pruritus was measured subjectively by a pruritus scale (0-3). Score 0: no itching, Score 1: mild itching but no significant disturbance of daily activities; Score 2: moderate itching causing disturbance of daily activities; Score 3: severe itching causing disturbance in night sleep.

Biopsy specimens $\left(3 \mathrm{~mm}^{2}\right.$ size and about $25 \mathrm{mg}$ weight) were taken from pruritic plaque skin lesions under topical anesthesia with $2 \%$ lidocaine and put into trizol or $\mathbf{4 \%}$ buffered paraformaldehyde. The samples in trizol were transferred via $-20^{\circ} \mathrm{C}$ rack to store at $-80^{\circ} \mathrm{C}$ until RNA extraction, while those in formalin were placed in the refrigerator for fixation.

\section{RNA extraction}

Total RNA was harvested in conformity with manufacturer's recommendations using trizol reagent (Invitrogen, Carlsbad, CA). Briefly described, skin biopsy specimens were homogenized in trizol by mean of an ultrasonic homogenator. After adding $200 \mu \mathrm{l}$ chloroform (Merck, Germany) and centrifuging at 12,000 rpm, RNA containing homogenates in the aqueous phase were separated, and the same volume of isopropranol was added. To avoid contamination with proteins, the lowest fraction of the aqueous phase was not incorporated into the total RNA sample. Following centrifugation, precipitated RNA was dissolved in ethanol at $75 \%$ and centrifuged again at $1200 \mathrm{rpm}$. Isolated RNA was eluted in $20 \mu \mathrm{l}$ RNAase-free water, and the quantity and integrity of RNA were measured by Nano Drop (ND-1000 UV - Vis spectrophotometer).

\section{Primer design}

The primer sets for TGF- $\beta 1$, TGF- $\beta 2$, TGF- $\beta$ receptor 1 , TGF- $\beta$ receptor 2 , and $\beta$-actin (control gene) are shown in Table 1.

\section{CDNA synthesis and Semi quantitative RT-PCR}

Aliquots of $500 \mathrm{ng}$ total RNA were reverse-transcribed to create first-strand complementary DNA by superscript III reverse-transcriptase (Invitrogen) according to the manufacturer's protocol. The resulting $1 \mu \mathrm{l}$ of cDNA was validated with PCR in a volume of $25 \mathrm{ml}$ containing $2.5 \mu \mathrm{l}$ buffer (10x Takara), $5 \mathrm{pm}$ deoxynucleoside triphosphate, $0.3 \mu \mathrm{L}$ rTq polymerase (Cinagene, Tehran, Iran) and $10 \mathrm{pm}$ primer mix. PCR was carried out in the same solution with heat held at $95^{\circ} \mathrm{C}$ for $3 \mathrm{~min}$, denaturation at $95^{\circ} \mathrm{C}$ for $30 \mathrm{sec}$, and annealing at $59^{\circ} \mathrm{C}, 57^{\circ} \mathrm{C}$, $58^{\circ} \mathrm{C}, 56^{\circ} \mathrm{C}, 57^{\circ} \mathrm{C}$, or $59^{\circ} \mathrm{C}$ for TGF- $\beta 1$, TGF- $\beta 2$, TGF- $\beta$ receptor 1 , TGF- $\beta$ receptor 2 , and $\beta$-actin, respectively, for $30 \mathrm{sec}$, extension at $72^{\circ} \mathrm{C}$ for $1 \mathrm{~min}$ (33 cycle), terminal extension at $72^{\circ} \mathrm{C}$ for $5 \mathrm{~min}$, and a terminal hold at $4^{\circ} \mathrm{C}$. PCR products were separated by $2 \%$ agarose gel 
Table 1 Primer designs and sequences for TGF- $\beta_{1}$, TGF- $\beta_{2}$, TGF- $\beta R_{1}$ and TGF- $\beta R_{2}$

\begin{tabular}{|c|c|c|c|}
\hline Product size & Annealing Time & Sequence & Name \\
\hline \multirow[t]{2}{*}{$242 \mathrm{bp}$} & 59 & 5'TCAAGCAGAGTACACACAGC3' & TGF- $\beta_{1}$ Forward Primer \\
\hline & 59 & 5'GCACAACTCCGGTGACATC3' & TGF- $\beta_{1}$ Reverse Primer \\
\hline \multirow[t]{2}{*}{$220 \mathrm{bp}$} & 57 & 5'TTGACGTCTCAGCAATGGAG3' & TGF- $\beta_{2}$ Forward Primer \\
\hline & 57 & 5'TCAGTTACATCGAAGGAGAGC3' & TGF- $\beta_{2}$ Reverse Primer \\
\hline \multirow[t]{2}{*}{$190 \mathrm{bp}$} & 56 & 5'TGCTGCAATCAGGACCATTG3' & TGF- $\beta R_{1}$ Forward Primer \\
\hline & 56 & 5'TCCTCTTCATTTGGCACTCG3' & TGF- $\beta R_{1}$ Reverse Primer \\
\hline \multirow[t]{2}{*}{$210 \mathrm{bp}$} & 57 & 5'TGCTCACCTCCACAGTGATC3' & TGF- $\beta R_{2}$ Forward Primer \\
\hline & 57 & 5'TCTGGAGCCATGTATCTTGC3' & TGF- $\beta R_{2}$ Reverse Primer \\
\hline \multirow[t]{2}{*}{$190 \mathrm{bp}$} & 59 & 5'TCATGAAGATCCTCACCGAG3' & $\beta$-actin Forward Primer \\
\hline & 59 & 5'TTGCCAATGGTGATGACCTG3' & $\beta$-actin Reverse Primer \\
\hline
\end{tabular}

electrophoresis, and the quantity of the bands was visually detectable under UV light after dying with ethidium bromide. All results were normalized with $\beta$-actin expression to compensate for differences in cDNA amount. Image analysis (using Scion Image software) was done to obtain quantitative data. (Scion Corporation, Frederick, MD)

\section{Immunohistochemistry}

Details of the immunohistochemistry are already described elsewhere [39]. In brief, skin biopsy specimens were placed in $4 \%$ buffered paraformaldehyde for fixation.

After immersion overnight in phosphate buffer containing $30 \%$ sucrose, $20 \mu \mathrm{m}$ thicktissue sections were cut on a cryostat and incubated with HO-1 antibody (1:200 dilution in phosphate buffer) for $12 \mathrm{~h}$ at $4^{\circ} \mathrm{C}$. The antibody used in this study was a mouse monoclonal $\operatorname{IgG}_{1}$ antibody raised against recombinant TGF- $\beta_{1}$ of human origin (Santa Cruz Biotechnology, Inc, USA) at a dilution of 1:200. After incubation with the primary antibody, the sections were washed with PBS and incubated with biotinylated anti-mouse secondary antibody (Santa Cruz

Biotechnology, Inc, USA). Antigen-antibody reaction sites were detectable using an ABC complex (avidinbiotinylated peroxidase complex) system (Vector Laboratory, Burlingame, CA, USA) with DAB as a substrate. For the negative control, phosphate-buffered saline (PBS) was substituted for the primary antibody.

\section{Statistical analysis}

Data were analyzed by one-way ANOVA followed by a Bonferroni's test for multiple comparisons (using SPSS version 13). A level of $P<0.05$ was considered statistically significant. All results were expressed as means \pm SD.

\section{Results}

\section{Clinical Findings}

The pruritus scale level was severe (category 3) for all patients previously exposed to SM, while that for the chronic contact dermatitis patients varied from mild (17.6\%) to moderate $(29.4 \%)$ and severe $(53.0 \%)$ levels (Table 2).

We also assessed dermal complications due to scratching in chemically injured and chronic contact dermatitis patients (Table 3).

There were no significant differences in excoriation, lichenification, erythema, or fissure between these two patient groups $(\mathrm{p}>0.05)$.

\section{Molecular Biological Findings}

Only two (11.7\%) of the 17 SM chemically-injured patient samples expressed the TGF- $\beta 1$ gene, in contrast to the chronic contact dermatitis patient samples (10 of the 17 expressing it: 58.8\%) and normal controls (4 of the five expressing it: $80 \%)$, the significantly low expression rate among the three groups $(\mathrm{p}=0.003)$. Only one

Table 2 Severity of pruritus according to the pruritus scale in chemically-injured and chronic contact dermatitis patients

\begin{tabular}{lcc}
\hline & $\begin{array}{c}\text { Chemically-injured } \\
\text { patients }\end{array}$ & $\begin{array}{c}\text { Chronic contact dermatitis } \\
\text { patients }\end{array}$ \\
\hline Mild & $0 \%$ & $17.6 \%$ \\
Moderate & $0 \%$ & $29.4 \%$ \\
Severe & $100 \%$ & $53.0 \%$ \\
\hline
\end{tabular}

Table 3 Dermal complications due to scratching in chemically-injured and chronic contact dermatitis patients

\begin{tabular}{|c|c|c|c|c|}
\hline & \multicolumn{2}{|c|}{$\begin{array}{l}\text { chemically-injured } \\
\text { patients }\end{array}$} & \multicolumn{2}{|c|}{$\begin{array}{l}\text { chronic contact dermatitis } \\
\text { patients }\end{array}$} \\
\hline & Yes & No & Yes & No \\
\hline Excoriation & 13 & 4 & 14 & 3 \\
\hline Lichenification & 15 & 2 & 13 & 4 \\
\hline Erythema & 14 & 3 & 14 & 3 \\
\hline Fissure & 2 & 15 & 3 & 14 \\
\hline
\end{tabular}


(5.9\%) of the 17 SM chemically-injured samples expressed the TGF- $\beta 2$ gene, in contrast to the chronic contact dermatitis-patient samples ( 3 of the 17 expressing it: $47 \%$ ) and normal controls (4 of the five expressing it: 80\%); the expression rates among the three groups were significantly different $(\mathrm{p}=0.002)$.

As the numerical comparison for TGF- $\beta$ receptors reveals, only two (11.7\%) of the 17 SM chemicallyinjured patient samples expressed the TGF- $\beta$ receptor 1 gene in contrast to the chronic contact dermatitis patient samples (13 of the 17 expressing it: 76.4\%) and the normal controls (4 of the five expressing it: $80 \%$ ); there were significant differences among the three groups $(\mathrm{p}=0.001)$. Two $(11.7 \%)$ of the $17 \mathrm{SM}$ chemically-injured patient samples expressed the TGF- $\beta$ receptor 2 gene in contrast to the chronic contact dermatitis-patient samples (9 of the 17 expressing it: 52.9\%) and normal controls (4 of the five expressing it: $80 \%$ ); the expression rates among the three groups were significantly different $(\mathrm{p}=0.006)$ (Figure 1$)$.

With regard to the expression intensity measured by densitometer (relative density of TGF- $\beta$ gene/ $\beta$-actin gene), the expression intensities for TGF- $\beta 1$ and $-\beta 2$ genes in the chemically-injured patient samples were $0.046 \pm 0.15$ and $0.013 \pm 0.05$, respectively, in contrast to those in the chronic contact dermatitis-specimens $(1.105 \pm 2.46$ and $0.495 \pm 0.88$, respectively) and that in normal ones $(0.436 \pm 0.74$ and $0.309 \pm 0.42$, respectively), with insignificantly low expression levels among the three groups ( $\mathrm{p}=0.20$ and $\mathrm{p}=0.08$ respectively). The expression intensities for TGF- $\beta$ receptor 1 and 2 genes in the positive specimens of SM chemicallyinjured patients were $0.046 \pm 0.13$ and $0.03 \pm 00.08$, respectively, in contrast to those in the chronic contact dermatitis patients $(0.433 \pm 0.45$ and $0.523 \pm 0.67$, respectively) and in the normal controls $(0.848 \pm 0.79$ and $0.573 \pm 0.70$, respectively). The expression rates among the three groups were significantly different $(\mathrm{p}=$ 0.001 and $\mathrm{p}=0.01$ respectively) (Figure 2, 3).

When the expression intensity and the severity of the pruritis are compared, there was a tendency for patients without genetic expression for TGF-b1 and TGF-b receptor 1 to have significantly increased severity $(\mathrm{p}=$ 0.04 and $p=0.01$ respectively), but patients without genetic expression for TGF -b2 and TGF-b receptor2 did not exhibit statistically significant increased severity $(\mathrm{p}=0.70$ and $\mathrm{p}=0.36$ respectively) (Table 4$)$.

\section{Localization of TGF- $\beta 1$ by immunohistochemistry}

The expression/localization of TGF- $\beta 1$, as a representative of the isoforms, was examined by immunohistochemistry in the present study. In the normal skin of controls, the immunoreactivity for TGF- $\beta 1$ was intense throughout all the layers of the epidermis, and no immunoreactivity is seen in the dermis (Figure 4-4A). In contrast, TGF- $\beta 1$-immunoreactivity was below the significant detection level throughout both the epidermis, which was increased in thickness (Figure 4-4C), and the

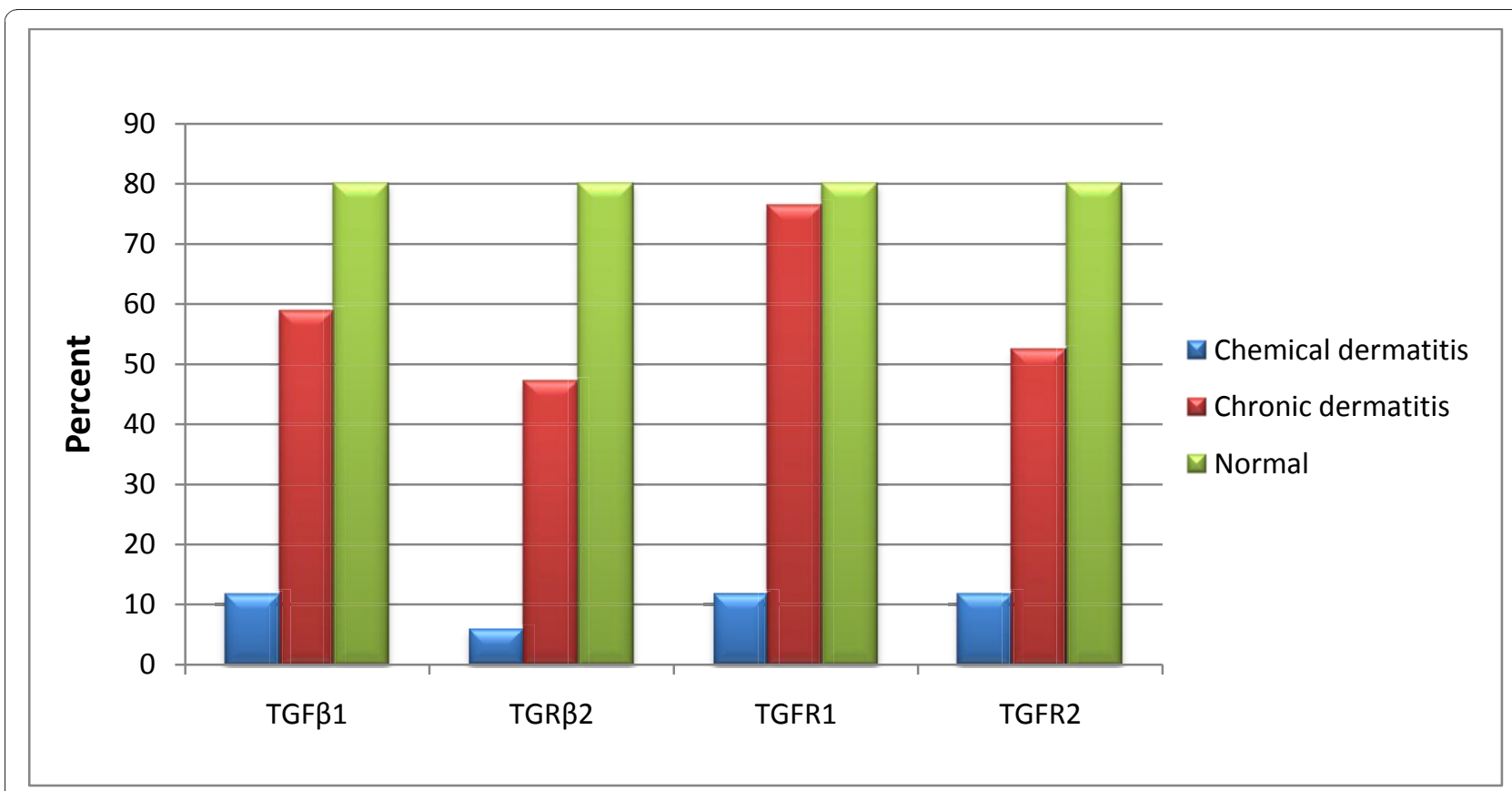

Figure 1 Prevalence of expression of TGF $\beta 1$, TGF $\beta 2$, TGFR1, and TGFR2 in patients with chemical dermatitis, those with chronic dermatitis, and normal individuals. 


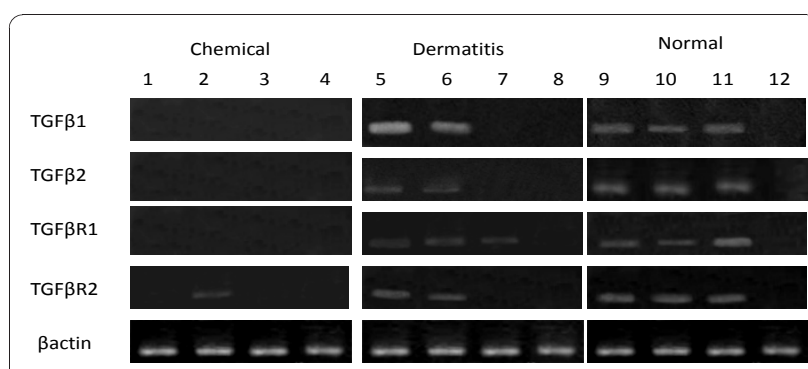

Figure 2 Gene expression of TGF $\beta 1$, TGF $\beta 2$, TGFR1, TGFR2 and Bactin in patients with chemical dermatitis, those with chronic dermatitis, and normal individuals measured by semiquantitative RT-PCR. TGF $\beta 1=242$ bp, TGF $\beta 2=220$ bp, TGFR1 = $190 \mathrm{bp}$, TGFR2 $=210 \mathrm{bp}$ and $\beta$ actin $=190 \mathrm{bp}$.

dermis of SM-chemically injured patients. On the other hand, in the skin of SM-independent chronic dermatitis patients, the immunoreactivity for TGF- $\beta 1$ was intense in the basal layer and moderate to weak in the other cell layers of the thickened epidermis (Figure 4-4B).

\section{Discussion}

Our results show that loss of expression of TGF- $\beta 1$, TGF$\beta 2$, TGF- $\beta$ receptor 1 , and TGF- $\beta$ receptor 2 genes in chemically injured patients is significantly more severe than in chronic contact dermatitis patients when compared with normal controls. Additionally, the frequency of severely pruritic cases is significantlyhigher in chemically injured patients than in chronic contact dermatitis patients.

Sulfur mustard and its effects on skin inflammation and the inflammatory cytokines have previously been examined in several different studies. In one animal study, the response of inflammatory cytokines was assessed in sulfur mustard-exposed mouse skin. The results emphasized the distinct role of IL- 6 as a proinflammatory biomarker in sulfur mustard skin injury $[13,14]$. In another study, alternations of gene expression of inflammatory cytokines were detected in sulfur mustard exposed skin; the results showed significant increases in the expression of inflammatory cytokines (IL-1B, GM-CSF, IL-6) following cutaneous sulfur mustard exposure [15].

It is well known that regulatory $\mathrm{T}$ lymphocytes produce TGF- $\beta$ and that these cells may also prepare IL-10, which, like TGF- $\beta$, has immunosuppressive effects [18]. In agreement with this fact, an interesting study has shown that overexpression of IL-10 following exposure to sulfur mustard can suppress the proinflammatory cytokines (IL-8 and IL-6) in human epidermal keratinocytes and lead to delayed cell death [40]. These findings are in agreement with our research results showing that TGF- $\beta$, like IL-10, can also have a distinct role in the modulation of skin inflammation of mustard gas. Loss of expression of TGF- $\beta$ s and their receptors in the skin lesions of chemical victims may lead to retention of inflammation in the skin and chronic skin manifestations like pruritus because of lack of TGF- $\beta$ control.

An animal investigation clearly reports that remarkable inflammatory lesions are detected in many organs of TGF- $\beta 1$-negative mice [35]. Moreover, severe immune pathology was detected in TGF- $\beta$ knockout mice [30], supporting our results.

The importance of the antiinflammatory role of TGF$\beta$ has been also emphasized in studies of signaling pathway mediators like Smad 3. These reports testify to this fact that TGF- $\beta$ signaling via Smad 3 has an important role in modulation of inflammation in atopic and

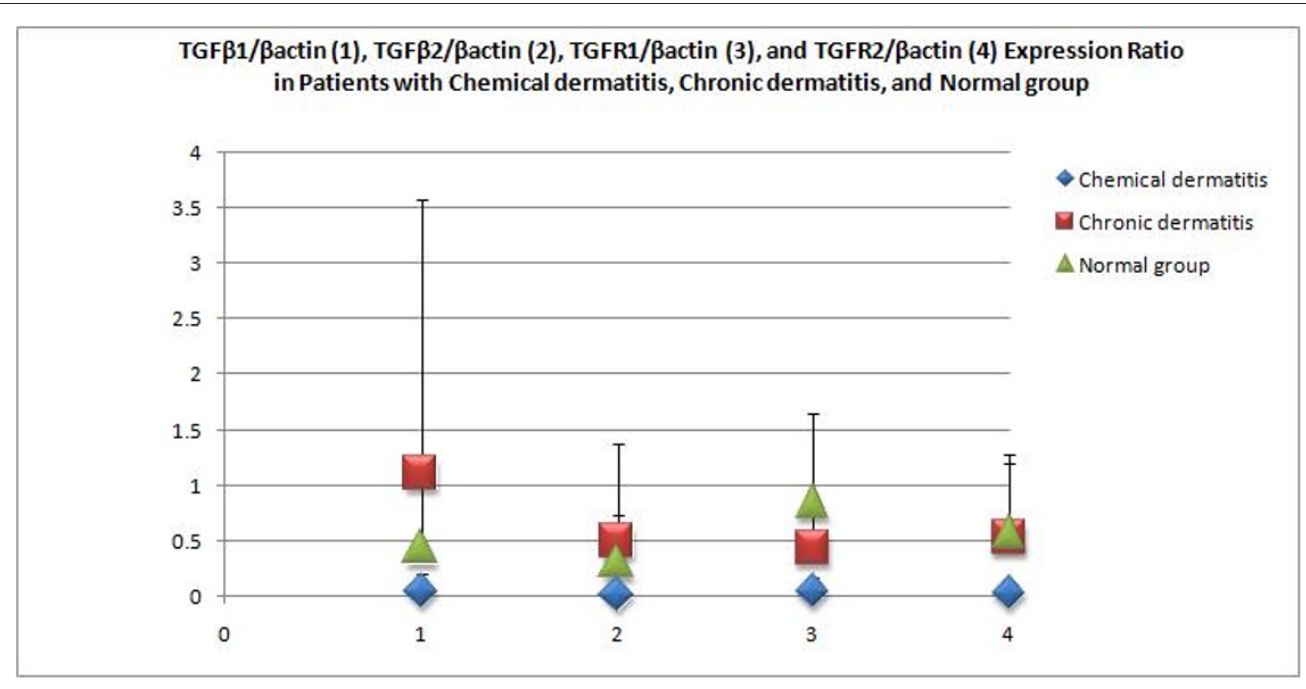

Figure 3 Relative density of TGF- $\beta$ genes/ $\beta$-actin gene as expression ratios measured by Scion-image software in patients with chemical dermatitis, those with chronic dermatitis, and normal individuals; the error bars show standard deviation (SD). 
Table 4 The relation between expression of TGF- $\beta$ genes and severity of pruritus (1: mild, 2: moderate and 3: severe) in all patients

\begin{tabular}{|c|c|c|c|c|c|}
\hline $\begin{array}{l}\text { Expression } \\
\text { of TGE } \beta \\
\text { receptor } 2\end{array}$ & $\begin{array}{l}\text { Expression } \\
\text { of TGE } \beta \\
\text { receptor } 1\end{array}$ & $\begin{array}{l}\text { Expression } \\
\text { of TGF- } \beta 2\end{array}$ & $\begin{array}{l}\text { Expression } \\
\text { of TGF- } \beta 1\end{array}$ & $\begin{array}{l}\text { Severity } \\
\text { of } \\
\text { pruritus }\end{array}$ & Num \\
\hline+ & + & - & - & 3 & 1 \\
\hline- & - & - & & 3 & 2 \\
\hline- & - & - & - & 3 & 3 \\
\hline- & - & - & - & 3 & 4 \\
\hline- & - & - & - & 3 & 5 \\
\hline- & - & - & + & 3 & 6 \\
\hline- & - & - & - & 3 & 7 \\
\hline- & - & - & + & 3 & 8 \\
\hline- & - & - & - & 3 & 9 \\
\hline- & - & - & - & 3 & 10 \\
\hline- & + & - & - & 3 & 11 \\
\hline- & - & - & - & 3 & 12 \\
\hline- & - & - & - & 3 & 13 \\
\hline- & - & - & - & 3 & 14 \\
\hline+ & - & + & - & 3 & 15 \\
\hline- & - & - & - & 3 & 16 \\
\hline- & - & - & - & 3 & 17 \\
\hline+ & + & + & + & 3 & 18 \\
\hline+ & + & + & + & 2 & 19 \\
\hline+ & + & - & + & 3 & 20 \\
\hline+ & + & + & + & 1 & 21 \\
\hline+ & + & + & - & 3 & 22 \\
\hline- & - & - & - & 3 & 23 \\
\hline- & + & - & - & 2 & 24 \\
\hline+ & + & - & + & 1 & 25 \\
\hline+ & + & + & + & 3 & 26 \\
\hline- & + & + & + & 2 & 27 \\
\hline- & - & + & - & 3 & 28 \\
\hline- & - & - & & 2 & 29 \\
\hline- & - & - & - & 3 & 30 \\
\hline+ & + & + & + & 3 & 31 \\
\hline- & + & - & + & 1 & 32 \\
\hline- & + & - & - & 2 & 33 \\
\hline+ & + & - & + & 3 & 34 \\
\hline
\end{tabular}

contact dermatitis; TGF- $\beta$ s and theirs signaling mediators bridle the inflammation flares mediated by other cytokines, chemokines, and inflammatory cells. In future studies, Smad molecules should be examined as possible targets in the skin lesions of chemical victims.

In some other studies, it has been demonstrated that TGF- $\beta$ has a important in wound healing; thus we see delays in wound healing in TGF 1 1-knockout mice [45]. This finding suggests that loss of expression of the
TGF- $\beta$ family in skin lesions of mustard gas may explain the chronic skin complaints of these patients.

Various studies have checked the expression of TGF- $\beta$ family and their receptors in normal skin and different regions; most of them agree that the expression of TGF $\beta 1$, 2,3 and TGF- $\beta$ R1, TGF- $\beta$ R2 (as mRNA or protein levels) is detectable in human keratinocytes and layers of the skin. Our investigation also detected this expression at the mRNA and protein levels, particularly in normal samples which usually express TGF- $\beta$ s and their receptors.

Matrix - Metallo proteinases (MMPs) also have a role in the inflammatory processes of sulfur mustard [50]; other research has shown that TGF- $\beta$ can inhibit MMPs $[29,51]$. Without the inhibitory control of TGF- $\beta$ s, these MMPs can be expected to continue their inflammatory effects. It has also been suggested that a lack of TGF- $\beta$ may play an important role in both hyperproliferation and malignant conversion in the skin and skin tumors [52].

Paradoxically, a few studies have described proinflammatory mechanisms of TGF- $\beta$ in skin pathologic conditions and its effects on chemo attraction [30,53-55]. These studies question the overall assumption that TGF- $\beta$ primarily has anti-inflammatory and immunomodulatory effects. Future investigations should clearly focus on analyzing TGF- $\beta$ roles in immunopathological processes.

Finally, it is important to consider studies which have assessed some therapeutic approaches to this type of poisoning. The use of anti-oxidants and inhibitors of NF-Kappa $\beta$ has been shown to be beneficial for sulfur mustard treated human keratinocytes [56,57].

Moreover, another study has suggested that the TGF- $\beta /$ Smad pathway can be useful in the treatment of atopic dermatitis [44].

Some other investigations have focused on the induction of TGF- $\beta_{1}$ and TGF- $\beta_{2}$ secretion by retinoic acid (isotretinoin) [58], which can lead to inhibitory effects of TGF- $\beta$ on both inflammation and proliferation in the skin $[59,60]$. Calcipotriol (a vitamin D3 analogue) has been described to increase the secretion and activation of TGF- $\beta 1$ and TGF- $\beta 2$ in murine skin cells [61]. In another study, tacrolimus ointment (FK506) appeared to upregulate TGF- $\beta$ release in keratinocytes as a treatment goal in dermatitis; this again reinforces an anti-inflammatory role for TGF- $\beta$ in skin disorders $[62,63]$.

These therapeutic studies may help us in future investigations targeting the TGF- $\beta$ family and its signaling pathway and designed to cure or diminish the chronic skin manifestations of sulfur mustard damage, including chronic pruritus, which is resistant to common remedies.

\section{Conclusions}

In summary, we clarified that most chemically injured patients did not express TGF- $\beta 1$, TGF- $\beta 2$, TGF- $\beta$ 

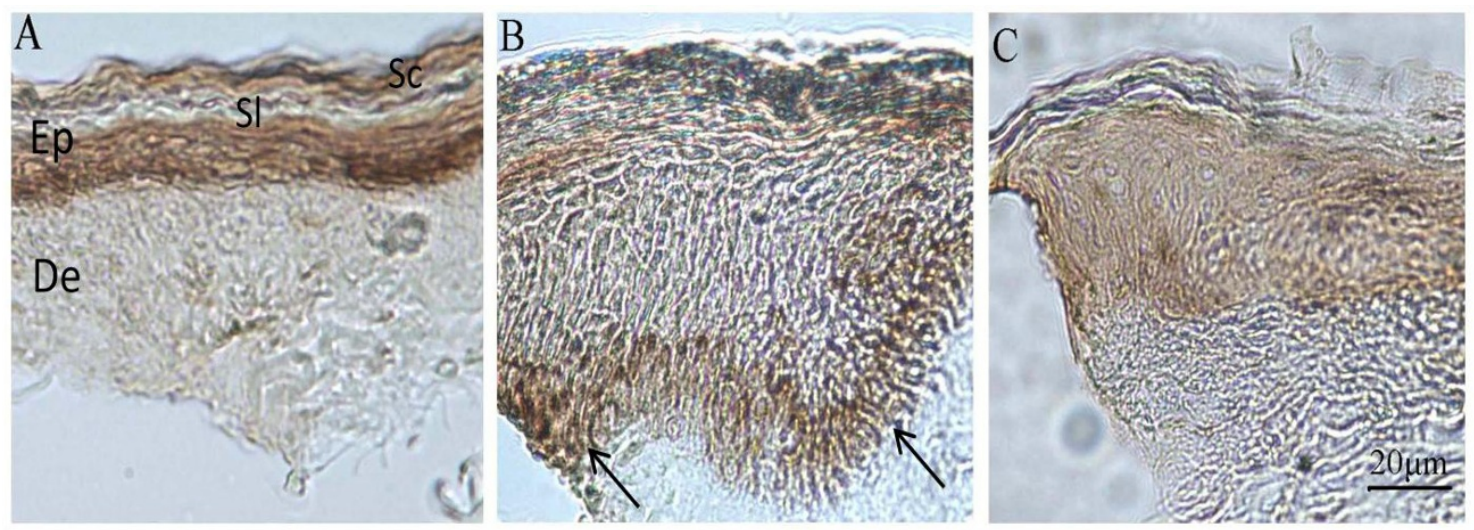

Figure 4 Immunohistochemical micrograph for TGF- $\beta 1$ in human skin. A, a section from a healthy person showing discrete cell levels in the stratum corneum (Sc), stratum lucidum (SI), epidermis (Ep) and dermis (De); TGF- $\beta 1$ was strongly expressed in epidermis of healthy skin. No immunoreactivity is seen in dermis of healthy skin. B, TGF- $\beta 1$ is intensely expressed in basal layer of epidermis of a chronic dermatitis patient. C, Epidermis of a chemically injured person weakly showed immunoreactivity for TGF- $\beta 1$ throughout the entire epidermis.

receptor 1 , or TGF- $\beta$ receptor 2 . All of this group of patients have severe pruritus as a chief complaint.

Nevertheless, detailed information about mustard gas effects on human skin, particularly at the molecular level, is very limited, and this investigation with such a small sample size cannot answer all the remaining questions. However, it can serve as a trigger for new research examining the molecular pathology of SM skin injury and thus developing new therapeutic approaches.

\section{Acknowledgements}

Research was supported by Chemical injury research center of Baqiyatallah University of Medical Sciences, Tehran-IRAN.

\section{Author details}

${ }^{1}$ Genomics Division, Chemical Injury Research Center (CIRC) Baqiyatallah University of Medical Sciences, Tehran-Iran. ${ }^{2}$ Research Center of Molecular Biology, Baqiyatallah University of Medical Sciences, Tehran-Iran. ${ }^{3}$ School of Medicine, Tehran University of Medical Sciences, Tehran-Iran.

\section{Authors' contributions}

IK carried out the molecular biology studies, alignment and drafted the manuscript, participated in the clinical examination data. SA clinical examination and taking biopsies. AAIF participated in the molecular biology analysis. ME participated in the molecular biology analysis. SY carried out the immunoassays. MS participated in the design of the study. YP participated in the design of the study. MRN as corresponding author participated in all stages of study and participated in its design and coordination and helped to draft the manuscript. All authors read and approved the final manuscript.

\section{Competing interests}

The authors declare that they have no competing interests.

Received: 15 December 2009 Accepted: 14 January 2011 Published: 14 January 2011

\section{References}

1. Kehe K, Szinicz L: Medical aspects of sulphur mustard poisoning. Toxicology 2005, 214(3):198-209.

2. Khateri $S$, et al: Incidence of lung, eye, and skin lesions as late complications in 34,000 Iranians with wartime exposure to mustard agent. J Occup Environ Med 2003, 45(11):1136-43.
3. Goodman LS, et al: Use of methyl-bis(beta-chloroethyl)amine hydrochloride and tris(beta-chloroethyl)amine hydrochloride for Hodgkin's disease, lymphosarcoma, leukemia and certain allied and miscellaneous disorders. JAMA 1984, 251:2255-2261.

4. Papirmeister $B$, et al: Pathology produced by sulfur mustard in human skin grafts on athymic nude mice II. J Toxicol 1984, 3:393-408.

5. Marrs TC, Maynard RL, Sidell FR: Chemical Warfare Agents. Toxicology and Treatment, Chichester 1996.

6. Khateri S, Ghanei M, Keshavarz S, et al: Incidence of lung, eye, and skin lesions as late complications in 34,000 Iranians with wartime exposure to mustard agent. J Occup Environ Med 2003, 45:1136-1143.

7. Somani SM: Chemical Warfare Agents. New York: Academic Press; 1992.

8. Petrali JP, Oglesby SB, Justus TA: Morphologic effects of sulfur mustard on a human skin equivalent. J. Toxicol. Cutaneous Ocul. Toxicol 1991, 10:315-324.

9. Momeni AZ, Enshaeih SH, Meghdadi M, et al: Skin manifestations of mustard gas A clinical study of 535 patients exposed to mustard gas. Arch Dermatol 1992, 128:775-780.

10. Hefazi M, Maleki M, Mahmoudi M, et al: Delayed complications of sulfur mustard poisoning in the skin and the immune system of Iranian veterans 16-20 years after exposure. Int J Dermatol 2006, 45:1025-1031.

11. Weisshaar E, Diepgen TL: Pruritus and quality of life. J Invest Dermatol 2005, 125:855-855

12. Skoet $R$, Zachariae $R$, Agner $T$ : Contact dermatitis and quality of life: A structured review of the literature. Br J Dermatol 2003, 149:452-456.

13. Arroyo CM, Schafer RJ, Kurt EM, Broomfield CA, Carmichael AJ: Response of normal human keratinocytes to sulfur mustard: Cytokine release. J Appl Toxicol 2000, 20:63-72.

14. Ricketts $K M$, Santai $C T$, France JA, et al: Inflammatory cytokine response in sulfur mustard-exposed mouse skin. J Appl Toxicol 2000, 20:73-76.

15. Sabourin CL, Petrali JP, Casillas RP: Alterations in inflammatory cytokine gene expression in sulfur mustard-exposed mouse skin. J Biochem Mol Toxicol 2000, 14:291-302.

16. Hunter J, et al: Clinical Dermatology., 3 2002, 2:18-28, 3: 37-38, 7: 70.

17. Thestrup-Pedersen $\mathrm{K}$, Larsen CG, Ronnevig J: The immunology of contact dermatitis: A review with special refrences to the pathophysiology of eczema. Contact dermatitis 1989, 20:81.

18. Nozaki S, Feliciani C, Sauder D: Keratinocyte cytokines In Advances in Dermatology. St. Louis: Mosby Year Book 1991.

19. Clark DA, Coker R: Transforming growth factor-beta (TGF- $\beta$ ). Int J Biochem Cell Biol 1998, 30:293-298.

20. Roberts AB: Molecular and cell biology of TGF- $\beta$. Miner Electrolyte Metab 1998, 24:111-119.

21. Wrana JL: TGF- $\beta$ receptors and signaling mechanisms. Miner Electrolyte Metba 1998, 24:120-130.

22. Derynk R, Zhang Y, Feng XH, Smads : Transcriptional activators of TGFbeta responses. Cell 1998, 95:737-40. 
23. Derynck R, Zhang YE: Smad-dependent and Smad-independent pathway in TGF-beta family signalling. Nature 2003, 425:577-84.

24. Moustakas A: Smad signalling network. J Cell Sci 2002, 115:3355-6.

25. Souchelnytskyi S, Rönnstrand L, Heldin $C H$, Tendijke P: Phosphorylation of Smad signaling proteins by receptor serine/threonine kinases. Methods Mol Biol 2001, 124:107-20.

26. Wrana J, et al: Mechanism of activation of the TGF- $\beta$ receptor. Nature 1994, 370:341-7.

27. Nakao A, Imamura T, Souchelnytskyi S: TGF- $\beta$ receptor-mediated signaling through Smad2, Smad3 and Smad4. J EMBO 1997, 16:5353-62.

28. Abbus KAbul, et al: Cellular and Molecular Immunology., 6 2003, 11:249-265, 268-271.

29. Kumar Vinay, et al: Robbins Basic Pathology., 8 2007, 3:63-65.

30. Letterio JJ, Roberts AB: Regulation of immune responses by TGF-beta. Annu Rev Immunol 1998, 16:137-61.

31. Gorelik L, Flavell RA: Transforming growth factor-beta in T-cell biology. Nat Rev Immunol 2002, 2:46-53.

32. Bogand C, Nathan C: Modulation of macrophage function by transforming growth factor beta, interleukin-4, and interleujin-10. Ann Ny Acad Sci 1993, 685:713-39.

33. Geissmann F, Revy P, Regnault A, et al: TGF-beta 1 prevents the noncognate maturation of human dendritic langerhans cells. J Immunol 1999, 162:4567-75

34. Chen W, Jin W, Hardegen N, et al: Conversion of peripheral CD4 + CD25 naive $T$ cells to $C D 4+C D 25$ + regularatory $T$ cells by TGF-beta induction of transcription factor Foxp3. J Exp Med 2003, 198:1875-86.

35. Kulkarni $A B$, huh $C-G$, Becker $D$, Geiser $A$, Lyght, Flanders $K C$, Roberts $A B$, Sporn MB, Ward JM: Transforming growth factor 1 null mutation in mice causes excessive inflammatory response and early death. Proc Natl Acad Sci 1993, 90:770-774.

36. Sellheyer K, Bickenbach JR, Rothangel JA, Bundman D, Longley MA, Krieg T, Roche Ns, Roberts AB, Roop DR: Inhibition of skin development by overexpression of transforming growth factor $\beta 1$ in the epidermis of transgenic mice. Pro Natl Acad Sci 1993, 90:5237-5241.

37. Malkani AK, Baker BS, Garioch JJ, powels AV, Lewise HM, Valdimarsson H, Fry L: Normal response to tumor necrosis factor- $a$ and transforming growth factor- $\beta$ by keratinocytes in psoriasis. Exp Dermatol 1993, 2:224-230.

38. Gambichler T, Tomi NS, Skrygan M, et al: Alterations of TGF-beta/Smad mRNA expression in atopic dermatitis following narrow-band ultraviolet B phototherapy: results of a pilot study. J Dermatol Sci 2006, 44:56-8.

39. Nourani MR, Owada Y, Kitanaka N, Abdelwahab SA, Iwasa H, Sakagami H, Spener F, Kondo H: Localization of epidermal-type fatty acid binding protein in macrophages in advanced atretic follicles of adult mice. $J \mathrm{Mol}$ Histol 2005, 36(6-7):391-400.

40. Qabar A, Nelson M, Guzman J, Corun Ch, Hwang BJ, Steinberg M: Modulation of sulfur mustard induced cell death in human epidermal keratinocytes using IL-10 and TNF-alpha. J Biochem Mol Toxicol 2005, 19:213-25.

41. Gambichler T, Tomi NS, Skrygan M, et al: Alterations of TGF-beta/Smad mRNA expression in atopic dermatitis following narrow-band ultraviolet B phototherapy: Results of a pilot study. J Dermatol Sci 2006, 44:56-8.

42. Antoni M, Fyhrquist-Vanni N, Wolff $\mathrm{H}$, et al: Transforming growth factor-b/ Smad3 signalling regulates inflammatory responses in a murine model of contact hypersensitivity. British J of Dermatology 2008, 159:546-554.

43. Anthoni M, Wang G, Deng Ch, Wolff HJ, Lauermaand Al, Alenius HT: Smad3 signal transducer regulates skin inflammation and specific lgE Response in murine model of atopic dermatitis. Journal of Investigative Dermatology 2007, 127:1923-1929.

44. Koji $\mathrm{S}$, et al: TGF-B/Smad signaling inhibits IFN-gamma and TNF-alphainduced TARC(CCL17) production in HaCa cells. Journal of dermatological science 2003, 31(1):53-8.

45. Crow JMaria, Doetschman T, Greenhalgh DG: Delayed wound healing in immunodeficient TGF-B1 knockout mice. Journal of Investigative Dermatology 2000, 115:3-11.

46. Matsuura H, Myokai F, Arata J, Noji S, Taniguchi S: Expression of type II transforming growth factor- $\beta$ receptor mRNA in human skin, as revealed by in situ hybridization. J dermatol Sci 1994, 8:25-32.

47. Schimid P, Cox D, Bilbe G, McMaster G, Morrison C, Stahelin H, Luscher N, Seiler W: TGF- $\beta$ s and TGF- $\beta$ type II receptor in human epidermis:
Differential expression in acute and chronic skin wounds. J pathol 1993, 171:191-197, 5150.

48. Schmid P, Itin P, Cherry G, Bi C, Cox Da: Enhanced expression of transforming growth factor- $\beta$ type I and type II receptors in wound granulation tissue and hypertrophic scar. Am J Pathol 1998, 152(2):485-493.

49. Schmid $P$, Itin $P$, Rufil TH: In situ analysis of transforming growth factors$\beta$ (TGF- $\beta$ 1, TGF- $\beta 2$, TGF- $\beta$ 3) and TGF- $\beta$ type II receptor expression in basal cell carcinomas. Br j Dermatol 1996, 134:1044-1051.

50. Sabourin CL, Danne MM, Buxton KL, Casillas RP, Schlager JJ: Cytokine, chemokine, and matrix metallo proteinase response after sulfur mustard injury to weanling pig skin. J Biochem Mol Toxicol 2002, 16:263-272.

51. Kuo YR, Wu WS, Jeng SF, Wang FS, Huang HC, Lin CZ, Yang KD: Suppressed TGF-beta1 expression is correlated with up-regulation of matrix metalloproteinase-13 in keloid regression after flashlamp pulseddye laser treatment. Lasers Surg Med 2005, 36(1):38-42.

52. Glick AB, Kulkarni AB, Tennenbaum $T$, et al: Loss of expression of transforming growth factor beta in skin and skin tumors is associated with hyperproliferation and a high risk for malignant conversion. Proc Natl Acad Sci USA 1993, 90(13):6076-6080.

53. He D, Wu Kim HK, et al: CD8 + IL-17-producing T cells are important in effector function for the elicitation of contact hypersensitivity responses. $\mathrm{J}$ Immunol 2006, 177:6852-8.

54. Veldhoen M, Hocking RJ, Atkins CJ, et al: TGF beta in the context of an inflammatory cytokine milieu supports de novo differentation of IL-17producing T cells. Immunity 2006, 24:179-89.

55. Ivanov II, McKenzie Bs, Zhou L, et al: The orphan nuclear receptor RORgammat directs the differentation program of proinflammatory IL-17 + T helper cells. Cell 2006, 126:1121-33.

56. Schulze-Osthoff K, Bauer MK, Vogt M, Wesselborg S: Oxidative stress and signsl transduction. Int J Vitam Nytr Res 1997, 67:336-342.

57. Schwager J, Schulze J: Influence of ascorbic acid on the responce to mitogens and interleukin production of porcine lymphocytes. Int J Vitam Nutr Res 1997, 67:10-16.

58. Batova A, Danielpour D, Pirisi L, Creek KE: Retinoic acid induces secretion of latent transforming growth factor $\beta 1$ and $\beta 2$ in normal and human papillomavirus type 16-immortalized human keratinocytes. Cell Growth Differ 1992, 3:763-772.

59. Tong PS, Horowitz NN, Wheeler LA: Trans retinoic acid enhances the growth response of epidermal keratinocytes to epidermal growth factor and transforming growth factor beta. J Invest Dermatol 1990, 94(1):126-131.

60. Creek KE, Geslani G, Batova A, Prisi L: Progressive loss of sensitivity to growth control by retinoic acid and transforming growth factor- $\beta$ at late stage of human papillomavirus type 16-initiated transformation of human keratinocytes. Advances in Experimental Medicine and Biology 1995, 375:117-135.

61. Koli K, Keski-Oja J: Vitamin D3 and calcipotriol enhance the secretion of transforming growth factor-beta 1 and beta 2 in cultured murine keratinocytes. Growth factors 1993, 8:153-163.

62. Lan CCE, et al: FK506 independently upregulates transforming growth factor $\beta$ and downregulates inducible nitric oxide synthase in cultured human keratinocytes: possible mechanisms of how tacrolimus ointment interacts with atopic skin. Journal of Investigative Dermatology 2000, 115:3-11.

63. Reitamo S, Wollenberg A, Scho"pf E, Perrot SL, Marks R, Ruzicka T, et al: Safety and efficacy of 1 year of tacrolimus ointment monotherapy in adults with atopic dermatitis. Arch Dermatol 2000, 136:999-1006.

\section{Pre-publication history}

The pre-publication history for this paper can be accessed here: http://www.biomedcentral.com/1471-5945/11/2/prepub

\section{doi:10.1186/1471-5945-11-2}

Cite this article as: Khaheshi et al.: Loss of expression of TGF- $\beta$ s and their receptors in chronic skin lesions induced by sulfur mustard as compared with chronic contact dermatitis patients. BMC Dermatology 2011 11:2. 